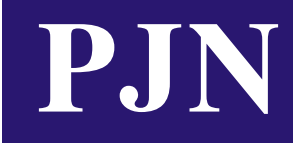

ISSN 1680-5194

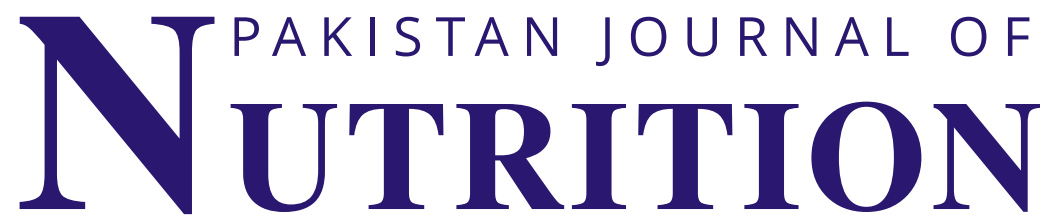

ANSI迫e佔

308 Lasani Town, Sargodha Road, Faisalabad - Pakistan Mob: +92 3003008585 , Fax: +92 418815544

E-mail: editorpjn@gmail.com 
Pakistan Journal of Nutrition 3 (4): 240-243, 2004

(C) Asian Network for Scientific Information, 2004

\title{
Effect of Heat and Tetracycline Treatments on the Food Quality and Acridity Factors in Cocoyam [Xanthosoma sagittifolium (L) Schott]
}

\author{
Enomfon J. Akpan ${ }^{1}$ and I.B. Umoh ${ }^{2}$ \\ ${ }^{1}$ Department of Biochemistry, Faculty of Basic Medical Sciences, \\ University of Uyo, Akwa Ibom State, Nigeria \\ ${ }^{2}$ Department of Biochemistry, College of Medical Sciences, \\ University of Calabar, Cross River State, Nigeria
}

\begin{abstract}
The effects of heat and drug (Tetracycline) treatments on the food quality of cocoyam-tannia [Xanthosoma sagittifolium (L) Schott] were studied. The proximate composition, mineral elements and anti nutritional factors of cocoyam were determined before and after various treatments. Moisture content decreased from $69.8 \%$ in the uncooked sample $\left(\mathrm{C}_{1}\right)$ to $67.62 \%$ in $\mathrm{C}_{2}$ cooked without drug. The decreases became more significant in various cooked samples $\mathrm{C}_{2}$ to $\mathrm{C}_{6}$ with different concentrations of tetracycline. Protein, fat, ash and fibre contents of the raw cocoyam (\% dry weight) were 2.83, 0.93, 1.74 and 0.88 respectively. The protein, fat, ash and fibre contents decreased to $1.48,0.72,1.70$ and 0.76 in the sample cooked without drug $\left(\mathrm{C}_{2}\right)$. Significant decreases were observed when samples $\mathrm{C}_{3}-\mathrm{C}_{6}$ were cooked with $1 \mathrm{~g}$ $(1000 \mathrm{mg})$ of Tetracycline as the values decreased to $1.13,0.48,1.33$ and 0.57 (\% dry wt) respectively. Mineral elements analysis showed general decreases in the cooked samples. There was a $17 \%$ reduction in calcium between $\mathrm{C}_{1}$ and $\mathrm{C}_{6}$ and similar trend was observed for other mineral elements. A general reduction in the level of anti nutrients was observed after heat and drug treatments. There was an improvement in food quality with respect to the anti nutrients but with decreased values of the desired nutrients. However, there was also a general reduction in the undesirable properties of the cocoyam such as the acridity factors caused by crystal of oxalate when the corms of cocoyam were cooked with and without Tetracycline.
\end{abstract}

Key words: Proximate composition, heat, Tetracycline, acridity factors

\section{Introduction}

The proximate and mineral composition of the common roots tubers in Nigeria have been reported by FAO (1968); Oyenuga (1968); Platt (1968); McCance and Widdowson (1979); Eka (1985); Ihekeronye and Ngoddy (1985); Osagie (1992). Available data reveal that the tubers and roots are eaten mainly as sources of energy since they contain carbohydrate, fat, fibre and protein although they are the poorest of all protein sources. It is needful therefore to eat them with other high protein foods. It is difficult to ascertain whether the roots and tubers can be relied upon as good sources of minerals because of the presence of anti nutritional factors, which render the minerals in them unavailable to the consumer.

Cocoyam (family: Araceae), a monocot, is an edible aroid and a major arable crop in Nigeria particularly in the South Eastern agricultural zone (Arene, 1987). There are two edible varieties in Nigeria-Colocasia esculentum (L) Schott (Taro) and Xanthosoma sagittifolium (L) Schott. (Tannia).

Cocoyam has the potential of meeting the energy requirements of the consumer, as it is very rich in good quality carbohydrates. Nutritionally the cormels of tannia are slightly superior to taro in energy and proteins; and, contain much less calcium, magnesium, zinc, and trypsin inhibitors than taro. Fresh tubers of tannia contain $20-30 \%$ starch and $1-4 \%$ proteins. Nearly all the calcium present is in the form of calcium oxalate (Onwueme, 1978; Bradbury and Holloway, 1988).

However, cocoyam consumption especially Xanthosoma has been affected by the presence of acridity factors which cause sharp irritation and burning sensation in the throat and mouth on ingestion of cooked corms (Sakai, 1979). The acrid compound may cause temporary sterility and has been directly linked to death of children and many experimental and domestic animals (Sakai, 1979; Tang and Sakai, 1983). This acridity has been associated more with aroids than with other root crops. A lot of factors implicated in acridity have been identified as crystals of calcium oxalate called Raphides (Agboola, 1987), proteinase inhibitors (Hammer, 1987), Taroin (Sakai, 1979), alkaloidglycoside, 3, 4-dihydrobenzaldehyde (Tang and Sakai, 1983), and prussic acid (Arene, 1987). The exact mechanisms of action of some of these factors are yet to be known. Removal of the thick layer of skin and long period of cooking is required to remove acridity (Sakai, 1979, 1983; Crabtree and Baldry, 1982). Other methods of removal of acridity include fermentation, baking or extraction with ethanol (Moy et al., 1979; Carpenter and Steinke, 1983; Tang and Sakai, 1983). There is also the selection and breeding of non-or low acrid cultivars of aroids. 
Akpan and Umoh: Effect of Heat and Tetracycline Treatments

A knowledge of the chemical composition of food would lead to a suggestion of a better cooking method that would minimize loss of desirable nutrients and elimination of the undesirable ones thus improving the nutritional value of foods. Tetracycline are commonly used in the removal; reduction or suppression of acridity factors in cocoyam.

Tetracycline, a semi synthetic crystalline powder is obtained from cultures of streptomyces. They are stable in acid solution with a $\mathrm{p}^{\mathrm{H}}$ greater than 2 but rapidly inactivated in neutral or alkaline solution.

Information is however scarce on the effect of drugs on the nutrient and anti nutrient composition of foods. This paper reports on the effects of heat (cooking) and drug (Tetracycline) treatments on the nutrient and anti nutrient composition of cocoyam (Xanthosoma sagittifolium).

\section{Materials and Methods}

Collection and Treatment of Samples: Fresh corms of cocoyam ( $X$. sagittifolium) were harvested from an open farm in Ikot Udodia Village in Etim Ekpo L.G.A., Akwa Ibom State, Nigeria in March 2000. Oral interview of the indigens of this village revealed that cocoyam grown in this area cause sharp throat irritation when the cooked corms are eaten. The cormels were peeled, washed, sliced into pieces and air-dried. They were then cut into six (6) equal portions of $50 \mathrm{~g}$ each, designated $\mathrm{C}_{1}$ to $\mathrm{C}_{6}$ as follows: $C_{1}$ (control) was further dried in a hot air circulating oven at $60^{\circ} \mathrm{C}$ for $24 \mathrm{hrs}$. The dried $\mathrm{C}_{1}$ sample was ground into fine powder using an electric blender, sieved and stored in an air-tight container for analysis. $\mathrm{C}_{2}$ was cooked for $2 \mathrm{hrs}$ without drug. $\mathrm{C}_{3}-\mathrm{C}_{6}$ were cooked for $2 \mathrm{hrs}$ with various concentration of Tetracycline ranging from $250 \mathrm{mg}$ to $1000 \mathrm{mg}$. Samples $\mathrm{C}_{2}-\mathrm{C}_{6}$ were dried after discarding the water, re-weighed, ground into powder, sieved and stored in properly labeled air-tight containers for analysis.

The recommended methods of the Association of Official Analytical Chemists (1975) were used for the determination of moisture, ash, crude fat, crude protein and crude fibre. Ash was obtained by the incineration of $25 \mathrm{~g}$ of the powdered sample in a muffle furnace at $550^{\circ} \mathrm{C}$ for six hours. Crude fat was determined by exhaustively extracting a known weight of the powder with petroleum ether (b.p. $40-60^{\circ} \mathrm{C}$ ), using a soxhlet apparatus. Protein $(\mathrm{N} \times 6.25)$ was determined by micro-kjeldahl method. Crude fibre was determined by the acid and alkaline digestion methods. Carbohydrate content was obtained by the 'difference' methods, that is, by subtracting the sum of protein, fat and fibre from the total organic matter. Multiplying the values of crude protein, fat and carbohydrate by 17,38 and 17 kilojoules respectively, taking the sum of the products and expressing the results in kilojoules obtained food energy.

The elemental composition of the sample was also determined by the methods of AOAC (1975). Sodium and potassium were determined by flame photometry where as other elements were determined by atomic absorption.

Total and soluble oxalates were determined by the method of Dye (1956). Hydro cyanic acid (HCN) was determined by the alkaline titration methods of AOAC (1975). Tannins were determined following the methods of Burns (1971), while phytic acid was determined by the methods of McCance and Widdowson (1953). All analyses were done in triplicates and average results computed using analysis of variance technique (Steel and Torrie, 1980).

\section{Results and Discussion}

Table 1 shows the proximate composition of the corms of Xanthosoma Sagittifolium before and after cooking with various concentrations of Tetracyclines. The moisture contents of $52.6-69.8 \%$ for $\mathrm{C}_{1}-\mathrm{C}_{2}$ compare well with $63-85 \%$ for taro and tannia (Bradbury and Holloway, 1988). The ash and crude protein showed decreases from $\mathrm{C}_{2}-\mathrm{C}_{6}$ with variation in drug concentration used for the test. The decrease in protein content may have been affected by tannins reported to form complexes with protein limiting their availability (Eka, 1985). However, the values reported for $C_{1}$ compare well with 1.99, 1.6, 2.2 and $2.1 \%$ reported for cassava, tannia, Discorea alata and Iris potato to respectively (Eka, 1998).

It has been observed that the fat level in cocoyam is generally low as in Table 1. However, the low level of fat in cocoyam may be beneficial for weight control Ash and carbohydrates were also affected when the samples were cooked with drug. Tuber and root crops are generally rich in carbohydrates (Eka, 1998).

The elemental compositions of $\mathrm{C}_{1}-\mathrm{C}_{6}$ are presented in Table 1. The analyses revealed that $\mathrm{Na}, \mathrm{K}, \mathrm{Mg}, \mathrm{P}$ and $\mathrm{Ca}$ were present in significant amounts in $\mathrm{C}_{1}$ while $\mathrm{Fe}, \mathrm{Zn}$, $\mathrm{Mn}$ and $\mathrm{Cu}$ were in trace amounts. From the results the effect of heat on nutrients in $\mathrm{C}_{1}$ and $\mathrm{C}_{2}$ cooked without drug is clear but become more pronounced when treated with tetracycline. The calcium content decreased from 18.64 in $\mathrm{C}_{1}$ to $9.36 \mathrm{mg} / 100 \mathrm{~g}$ in $\mathrm{C}_{6}$. These values are however, higher than $8.5 \mathrm{mg} / 100 \mathrm{~g}$ reported for tannia by Bradbury and Holloway (1988) but lower than $32 \mathrm{mg} / 100 \mathrm{~g}$ reported for taro (Arene, 1987).

The use of Tetracycline in the suppression of acridity could have been useful if it had no drastic effects on the nutrients. Tetracyclines are reported to chelate divalent and trivalent cations including $\mathrm{Al}, \mathrm{Ca}, \mathrm{Fe}, \mathrm{Mg}$ and $\mathrm{Zn}$ to form insoluble complexes (Trease and Evans, 1989). The reaction may be responsible for the reduction in essential nutrients in the cooked corms of cocoyam.

Table 1 also shows the levels of anti nutrients in the cooked and uncooked samples. The values for $C_{1}$ reduced on cooking without drug to 80.6 and $85.16 \mathrm{mg} / 100 \mathrm{~g}$ for total and soluble oxalates 
Akpan and Umoh: Effect of Heat and Tetracycline Treatments

Table 1: Effect of heat and tetracycline treatments on the food quality of cocoyam [Xanthosoma sagittifolium (L) Schott]

\begin{tabular}{|c|c|c|c|c|c|c|}
\hline \multirow{3}{*}{ Constituents } & \multirow{3}{*}{$\begin{array}{l}\text { Uncooked } \\
\text { corm }\left(\mathrm{C}_{1}\right)\end{array}$} & \multirow{3}{*}{$\begin{array}{l}\text { Cooked } \\
\text { corm } \\
\text { without } \\
\text { drug } \\
\left(\mathrm{C}_{2}\right)\end{array}$} & \multicolumn{4}{|l|}{ Contents } \\
\hline & & & \multicolumn{4}{|c|}{ Cooked corm with various concentrations of tetracycline } \\
\hline & & & $\mathrm{C}_{3}(250 \mathrm{mg})$ & $\mathrm{C}_{4}(500 \mathrm{mg})$ & $\mathrm{C}_{5}(750 \mathrm{mg})$ & $\mathrm{C}_{6}(1000 \mathrm{mg})$ \\
\hline \multicolumn{7}{|l|}{ Proximate values (g/100\%DM) } \\
\hline Moisture (wet weight) & $69.81 \pm 0.11$ & $67.62 \pm 0.42$ & $62.58 \pm 0.92$ & $60.42 \pm 0.17$ & $57.71 \pm 0.23$ & $52.63 \pm 0.76$ \\
\hline Crude proteins & $2.83 \pm 0.30$ & $1.48 \pm 0.37$ & $1.40 \pm 0.01$ & $1.36 \pm 0.10$ & $1.28 \pm 0.51$ & $1.13 \pm 0.81$ \\
\hline Crude fat & $0.93 \pm 0.10$ & $0.72 \pm 0.51$ & $0.69 \pm 061$ & $0.63 \pm 0.10$ & $0.52 \pm 0.17$ & $0.48 \pm 0.03$ \\
\hline Crude fibre & $0.88 \pm 0.41$ & $0.76 \pm 0.23$ & $0.73 \pm 0.13$ & $0.70 \pm 0.07$ & $0.67 \pm 0.48$ & $0.51 \pm 0.96$ \\
\hline Ash & $1.74 \pm 0.25$ & $1.70 \pm 0.25$ & $1.67 \pm 0.08$ & $1.50 \pm 0.18$ & $1.42 \pm 0.16$ & $1.33 \pm 0.77$ \\
\hline Carbohydrates & $93.62 \pm 1.06$ & $95.34 \pm 1.36$ & $95.51 \pm 0.83$ & $95.81 \pm 0.36$ & $96.11 \pm 1.32$ & $96.55 \pm 2.57$ \\
\hline $\begin{array}{l}\text { Caloric value (Kilojoule/100g) } \\
\text { Minerals (mg/100g) }\end{array}$ & 1574.99 & 1673.30 & 1673.69 & 1675.83 & 1675.39 & 1678.80 \\
\hline Sodium & $66.15 \pm 0.42$ & $64.03 \pm 0.13$ & $61.43 \pm 0.18$ & $56.28 \pm 0.13$ & $51.42 \pm 0.87$ & $45.22 \pm 0.24$ \\
\hline Potassium & $524.95 \pm 0.51$ & $516.24 \pm 0.07$ & $508.16 \pm 0.31$ & $471.42 \pm 0.11$ & $443.31 \pm 0.91$ & $98.72 \pm 0.31$ \\
\hline Magnesium & $46.60 \pm 0.21$ & $43.64 \pm 0.24$ & $39.24 \pm 0.84$ & $33.98 \pm 0.41$ & $27.38 \pm 0.16$ & $24.71 \pm 0.36$ \\
\hline Calcium & $18.64 \pm 0.03$ & $15.42 \pm 0.36$ & $15.42 \pm 0.19$ & $11.32 \pm 0.07$ & $9.70 \pm 0.22$ & $9.36 \pm 0.38$ \\
\hline Iron & $0.42 \pm 0.44$ & $0.41 \pm 0.17$ & $0.38 \pm 0.27$ & $0.31 \pm 0.18$ & $0.23 \pm 0.81$ & $0.16 \pm 0.64$ \\
\hline Phosphorus & $70.41 \pm 0.26$ & $69.27 \pm 0.21$ & $67.79 \pm 0.32$ & $61.27 \pm 0.86$ & $52.60 \pm 0.37$ & $47.61 \pm 0.21$ \\
\hline Zinc & $0.46 \pm 0.18$ & $0.33 \pm 0.09$ & $0.31 \pm 0.74$ & $0.27 \pm 0.32$ & $0.19 \pm 0.17$ & $0.12 \pm 0.82$ \\
\hline Manganese & $0.63 \pm 0.02$ & $0.59 \pm 0.18$ & $0.55 \pm 0.77$ & $0.52 \pm 0.44$ & $0.47 \pm 0.58$ & $0.38 \pm 0.74$ \\
\hline Copper & $0.24 \pm 0.16$ & $0.21 \pm 0.22$ & $0.19 \pm 0.02$ & $0.18 \pm 0.31$ & $0.15 \pm 0.84$ & $0.13 \pm 0.16$ \\
\hline \multicolumn{7}{|l|}{ Anti-nutrients (mg/100\%) } \\
\hline Total oxalate & $86.78 \pm 0.81$ & $80.6 \pm 0.05$ & $50.1 \pm 0.31$ & $48.46 \pm 0.77$ & $42.64 \pm 0.61$ & $38.61 \pm 0.64$ \\
\hline Soluble oxalate & $96.42 \pm 0.54$ & $85.16 \pm 0.13$ & $49.8 \pm 0.47$ & $46.73 \pm 0.60$ & $41.36 \pm 0.19$ & $35.16 \pm 0.72$ \\
\hline Hydrocyanic acid & $21.02 \pm 0.36$ & $19.04 \pm 0.27$ & $17.61 \pm 0.56$ & $15.18 \pm 0.71$ & $13.47 \pm 0.71$ & $12.68 \pm 0.95$ \\
\hline Tannins & $640.12 \pm 0.24$ & $520.51 \pm 0.14$ & $508.29 \pm 0.14$ & $460.11 \pm 0.41$ & $409.18 \pm 0.43$ & $372.71 \pm 0.43$ \\
\hline Phytate & $39.21 \pm 0.06$ & $30.16 \pm 0.18$ & $28.14 \pm 0.36$ & $25.71 \pm 0.47$ & $21.71 \pm 0.18$ & $19.12 \pm 0.17$ \\
\hline
\end{tabular}

respectively. Reductions became more significant when samples were cooked with various concentrations of Tetracycline. All tubers are reported to contain insoluble oxalate as calcium oxalate, and soluble oxalates. The oxalates have been implicated as a mechanical defense mechanism, storage reserves and stores of excess calcium (Raven and Smith, 1976; Sunell and Healey, 1979; Smith, 1982). Consumption of large doses of oxalic acid limits the availability of $\mathrm{Ca}, \mathrm{Mg}, \mathrm{Fe}$ and $\mathrm{P}$ forming insoluble compounds or salts with the minerals (Eka, 1985). Oxalates are reported to cause corrosive gastroenteritis, shock, convulsive symptoms, low plasma calcium, high plasma oxalates and renal damage (Fassett, 1973; Connor, 1977; Hodkinson, 1977; Kelsey, 1985; Passmore and Eastwood, 1986). While cows, sheep and goats can utilize calcium oxalate, it is only poorly utilized by man. The amount of soluble oxalate in tubers is comparatively small. The peels of tubers contain more oxalate than the peeled tubers. This supports the role of oxalate; as allelochemicals (Wills et al., 1983, Holloway et al., 1988).

The hydrocyanic acid, tannins and phytate contents reduced in $C_{1}$ from $21.02,640.12$ and $39.21 \mathrm{mg} / 100 \mathrm{~g}$ to 19.04, 520.51 and 30.16 in $C_{2}$ respectively. When cooked with $1000 \mathrm{mg}$ of Tetracycline $\left(\mathrm{C}_{6}\right)$ the $\mathrm{HCN}$ content reduced to $12.68 \mathrm{mg} / 100 \mathrm{~g}$. Tannins and phytate also reduced significantly when samples were cooked with drug.
It is evident from Table 1 that heat treatments during cooking reduced the levels of the anti nutrients. Thus the food quality improves with respect to the levels of these anti nutrients, some of which are responsible for acridity but reduces the food quality with respect to the levels of the mineral elements. It is believed that supplementation from other cheap sources of these nutrients such as vegetables usually eaten with the cooked cocoyam could improve the levels of these elements. However, reductions in anti nutrients, which constitute the undesirable properties, imply a possible suppression or reduction in acridity factors. For this practice to be of value to the consumers the cocoyam must be eaten with locally available vegetables and legumes so as to supplement the lost nutrient due to heat or drug treatment.

\section{References}

Agboola, S.D., 1987. Cocoyam storage and its potential for food sufficiency and future economic recovery of Nigeria In: Arene, O. B. (ed). Cocoyam in Nigeria: production, storage, processing and utilization, p: 65 . AOAC., 1975. Official methods of Analysis. $12^{\text {th }}$ ed Association of Official Analytical chemists, Washington, D. C.

Arene, O.B., 1987. Allochemicals in Aroids: sequence of a proteinase inhibitor from Allocasia macrorrhiza. Ph. D. Thesis, Australian National University, Canberra, Australia. 
Akpan and Umoh: Effect of Heat and Tetracycline Treatments

Bradbury, J.H. and W.D. Holloway, 1988. Chemistry of Tropical root crops: Significance for nutrient and Agriculture in the Pacifics. ACIAR. Monograph No. 6, p: 201.

Burns, R.E., 1971. Method of estimation of tannin in grain sorghum. Agron. J., 63.511.

Carpenter, J.R. and W.E. Steinke, 1983. Animal feed. In Wang, J. ed. Taro a review of Colocasia esculenta and its potentials. Honolulu, University of Hawaii Press, 200-269.

Connor, H.E., 1977. The poisonous plants in New Zealand. Wellington. New Zealand Government printers p: 134.

Crabtree, J. and J. Baldry, 1982. Technical note: the use of taro products in breed making. J. Food Tec., 17: 771-777.

Dye, W.B., 1956. Studies on Halogton glomerulus, Weed, 4: 55-56.

Eka, O.U., 1985. The chemical composition of yam tubers. In: Advance in yam Research. The biochemical and technology of yam tuber vol. 1 Osuji, G. ed. Published by Biochemical Society of Nigeria in collaboration with ASUTECH. Eungu, Nigeria, pp: 5175.

Eka, O.U., 1998. Roots and Tubers In: Osagie, A. U. and Eka, O. U. (eds) Nutrition Quality of plant foods, pp: 131.

Fassett, D.W., 1973. Oxalates. In: Toxicants occurring naturally in foods. Washington D.C. National Academy of Sciences, 346-362.

F.A.O., 1968. Food composition table for use in Africa Rome, Italy. Food and Agriculture organization of the United Nations.

Hammer, B.C., 1987. A study of proteinase inhibitors in the edible aroids. Ph. D. Thesis. Australian National University, Canberra.

Hodkinson, A., 1977. Oxalic acid in Biology and Medicine, London. Academy press, P: 207.

Holloway, W.D., M.E. Argall, W.T. Jealous, J.A. Lee and J.H. Bradbury, 1988. In: Eka, O. U. (1998) roots and Tubers In: Osagie, A. U. and Eka, O. U. (eds) Nutrition Quality of plant foods, pp: 1-31.

Ihekeronye, A.I. and P.O. Ngoddy, 1985. Integrated food Science and Technology for the tropics. McMillan publisher's Ltd. London, pp: 266-282 and 366-368.

Kelsey, J.L., 1985. Effect of Oxalic acid on calcium bioavailability In: Kies C. ed. Nutritional bioavailability of calcium. Washington. D. C. American chem. Soc., 105-106.

McCance, R.A. and E.M. Widdowson, 1953. Phytin in Human Nutrition, Br. J. Nutr., 29: 16-24.

McCance, R.A. and E.M. Widdowson, 1979. The composition of foods. Her majesty's stationary office, London, p: 417.
Moy, J.H.B. Shabolt, G.S. Stoewsand and T.O.M. Nakayama, 1979. The acridity factor in taro processing. J. Fd. Processing and preservation, 3: 139-144.

Onwueme, I.C., 1978. The tropical tuber crops: yams, cassava, sweet potatoes, and cocoyams Chichester, John Wiley and Sons, p: 234.

Osagie, A.U., 1992. The yam tuber in storage. An up-todate review of the biochemical composition and storage of the yam tuber. Published by post harvest Research Unit. Dept. of Biochemistry, University of Benin, Nigeria. p: 247.

Passmore, R. and M.A. Eastwood, 1986. Davidson and Passmore Human Nutrient and Dietetics, $8^{\text {th }}$ edn. Churchill Living stone, Edinburgh.

Platt, E.S., 1968. Table of representative values of food used in tropical countries. Medical Res. Council. Special report, No. 302, London.

Raven, J.A. and F.A. Smith, 1976. Nitrogen assimilation and transport in vascular land plants in relation to Intracellular $\mathrm{P}^{\mathrm{H}}$ regulation. New Phytologist, 76. 415436.

Sakai, W.S., 1979. Aroid root crops acridity and raphides. In: inglett, G. E. and Charalampous, G. ed. Trop. Foods, Chemistry and Nutrition Vol 1. New York, Academic press, 265-278.

Sakai, W.S., 1983. Aroid root crops In: Chan, H. T. ed. Handbook of Trop. New York, Marcel Dekker 29-83.

Smith, D.L., 1982. Calcium Oxalate and carbonate deposits in plant cells In: Anghileri, L. J. and TuffetAnghileri, A. M. ed. The role of Calcium in biological systems. CRC. Press Poca Raton, Florida, p: 253261.

Steel, R.G.D. and J.H. Torrie, 1980. Principles and procedures of Statistics, McGraw Hill Book co., New York.

Sunell, L.A. and P.L. Healey, 1979. Distribution of Calcium Oxalated idioblast in corms of taro. Colocasia esculenta. Amer. J. Bot., 66: 1029-1032.

Tang, C.S. and W.W. Sakai, 1983. Acridity to taro and related plants in Araceae In: Wang, J. K. ed. Taro a review of Colocasia esculenta and its potentials. Honolulu, University of Hawaii press, 148-164.

Trease, C.E. and W.C. Evans, 1989. Trease and Evans Pharmacognosy, $13^{\text {th }}$ ed., Bailliere, Tindal, London (pub) pp: 17-39.

Wills, R.B.H. J.S.L. Lim, H. Greenfield and Bayliss, T. Smith, 1983. Nutrient composition of taro. C. esculenta cultivars from Papua New Guinea Highlands. J. Sci. Food and Agri., 34: 1137-1142. 